\title{
Bovine MHC class II DR molecule plays a key role in bovine leukemia virus (BLV)-induced lymphoma
}

\author{
Yoko Aida1*, Shin-nosuke Takeshima1', Yuki Matsumoto', Taku Miyasaka', Yoshiyuki Miyazaki², Yoshihiro Tanabe²,
} William C Davis ${ }^{3}$, Kosuke Okada ${ }^{4}$

From 15th International Conference on Human Retroviruses: HTLV and Related Viruses

Leuven and Gembloux, Belgium. 5-8 June 2011

BLV is the etiological agent of enzootic bovine leukosis (EBL), which emerges as B-cell lymphomas. Previously, we found one of tumor-associated antigens (TAAs), which is a useful tool not only for diagnosing EBL but also for screening of BLV-infected cattle with the potential to develop tumor in the future, by using the monoclonal antibody (MAb) c143. We here performed biochemical characterization of c143 TAA such as twodimensional electrophoresis, sequential immunoprecipitation and tryptic peptide mapping with c143 MAb as well as MAbs against bovine major histocompatibility complex (BoLA) class II antigens, and flow cytometry and immunofluorescence staining of cells transiently transfection with a combination of BoLA-DRA, -DRB3, $-D Q A$ and $-D Q B$ cDNAs. First, it was found that the c143 TAA is BoLA-DR consisting of alpha and beta chains. Furthermore, the altered expressions of c143 TAA were observed in infected animal with lymphoma at various stages as follows: 1) The number of cells positive for the c143 TAA and 2) glycosylation of the beta chain increased with the progression of EBL. 3) The beta chain was specifically phosphorylated at serine residue(s) during the lymphoma stage. Finally, we tested an association of microsatellite markers using 86 cattle with lymphoma and 320 asymptomatic cattle. We identified that seven genomic markers which located in chromosomes $1,3,9,15,21,23$ and 24, and, in addition, BoLA-DRB3 gene in chromosomes 23 , showed suggestive linkage to development of the BLV-induced EBL.

\footnotetext{
* Correspondence: aida@riken.jp

'Viral Infectious Diseases Unit, RIKEN, 2-1 Hirosawa, Wako, Saitama, 351-0198, Japan

Full list of author information is available at the end of the article
}

Collectively, our results strongly indicate that BoLA-DR plays a key role in BLV-induced diseases progression.

\section{Author details}

${ }^{1}$ Viral Infectious Diseases Unit, RIKEN, 2-1 Hirosawa, Wako, Saitama, 351-0198, Japan. ${ }^{2}$ Maebashi Institute of Animal science, Livestock Improvement Association of Japan. ${ }^{3}$ Department of Veterinary Microbiology and Pathology, Washington State University, Pullman, WA, 99164-7040, USA. ${ }^{4}$ Department of Veterinary Pathology, Faculty of Agriculture, Iwate University, Morioka, 020-8550, Japan.

Published: 6 June 2011

doi:10.1186/1742-4690-8-S1-A7

Cite this article as: Aida et al:: Bovine MHC class II DR molecule plays a key role in bovine leukemia virus (BLV)-induced lymphoma. Retrovirology 2011 8(Suppl 1):A7.

\section{Submit your next manuscript to BioMed Central and take full advantage of: \\ - Convenient online submission \\ - Thorough peer review \\ - No space constraints or color figure charges \\ - Immediate publication on acceptance \\ - Inclusion in PubMed, CAS, Scopus and Google Scholar \\ - Research which is freely available for redistribution

C Biomed Central

(c) 2011 Aida et al; licensee BioMed Central Ltd. This is an open access article distributed under the terms of the Creative Commons Attribution License (http://creativecommons.org/licenses/by/2.0), which permits unrestricted use, distribution, and reproduction in any medium, provided the original work is properly cited. 